\title{
The concept of just war in Russian and American linguistic cultures
}

\author{
Ekaterina L. Kabakhidze ${ }^{1^{*}}$, Marina A. Belogash ${ }^{2}$, and Elena L. Avdeeva ${ }^{2}$ \\ ${ }^{1}$ Financial University under the Government of the Russian Federation, Department of Humanities, \\ Moscow, Russia \\ ${ }^{2}$ Financial University under the Government of the Russian Federation, Department of English for \\ Professional Communication, Moscow, Russia
}

\begin{abstract}
The study examines the concept of just war in the militarypolitical discourse and technologies of manipulating the mass consciousness used by the leaders of the Russian and American states in speeches based on the idea of just war. Lexical and semantic analysis of the lexemes "just" and "war" in Russian and English is carried out. The relevance of the study is determined by the increasing attention to the military-political discourse and actualization of the concept. It received consistent substantiation and development in the works of medieval scholastics. In the 21 st century, it serves the purposes of moral and ethical justification of modern military conflicts. The purpose of the study was to analyze the concept of just war at the lexical and semantic level and describe its ontological foundations and implementation in the Russian and American mental lexicons. Based on the analysis, the authors have identified general and particular aspects of the just war concept in the Russian and American mental lexicons and described the mechanisms of mind control in the political discourses of B. Obama and V.V. Putin.
\end{abstract}

Keywords: just war, military-political discourse, consciousness.

\section{Introduction}

I. Kant revolutionized philosophy in the $18^{\text {th }}$ century by placing man in the center of the universe. Russian and foreign linguists and philosophers of the second half of the $20^{\text {th }}$ century, with the development of anthropocentric linguistics, placed discourse in the center of the universe next to man.

Homo loquens realizes itself in speech activity, the products of which are speech or texts. Quoting K.F. Sedov, speech products are the result of the discursive activity of a linguistic personality and thinking: "At the same time, they allow to talk $<\ldots>$ about the hidden (latent) processes of their linguistic consciousness, which constitute the peculiarity of the discursive thinking of Homo loquens" [1, 2].

According to V.V. Krasnykh and V.N. Teliia, the discursive thinking of Homo loquens is characterized by ethnocultural or linguocultural self-identification of the individual [3].

\footnotetext{
* Corresponding author: elkabakhidze@,fa.ru
} 
Discourse is an integral speech product in unity with its communicative and cognitive functions, generated and interpreted by the consciousness of the individual. "Consciousness is composed and realized in the symbolic material created in the process of social communication of an organized collective", writes M.M. Bakhtin [4].

S. Freud's concept about levels of consciousness allows expanding the aforementioned thesis, specifying that the discourse covers all levels of consciousness - id, super-ego, and ego [5].

Reflecting on the features of political discourse, V.Z. Demiankov notes its essential characteristic - a manipulative speech effect on the addressee. An author of the discourse creates a special mental world, immersing the interpreter in it, having previously prepared the interpreting consciousness for the "correct" attitude to the subject of speech [6].

Manipulation is best represented in the military-political discourse. According to O.V. Sokolova, its purpose is to become not a metaphorical struggle for power, but the direct conduct of war [2]. The performance, agonality, and polymy of the military-political discourse significantly expand the arsenal of means and mechanisms of speech manipulation of the addressee's consciousness.

The speech of a politician (with some exceptions) operates with symbols, and its success is predetermined by the extent to which these symbols are in tune with the mass consciousness. A politician must be able to touch a chord in this consciousness. A politician's statements should fit into the universe of opinions and assessments (that is, in the whole set of inner worlds) of their addressees, consumers of political discourse [6].

Political communication as a whole affects the distribution and use of power due to the fact that "it serves as a means of influencing the consciousness of people making political decisions (voters, politicians, officials, etc.)" [7, 8]. Thus, political communication not only conveys information, but has an emotional impact and transforms reality in the mind of the addressee. We find a similar thought in T. van Dijk's article Principles of Critical Discourse Analysis: "Power involves control... Such control may pertain to action and cognition... by persuasion, dissimulation or manipulation, among other strategic ways to change the mind of others in one's own interests" [9].

Thus, military-political discourse aimed at compulsion, captures all levels of human consciousness and immerses it in a special mental world. It influences the discursive thinking of the individual and modifies the opinions, intentions, and behavior of the addressee.

\section{Methods}

The subject of the study is the concept of just war, which is actively used in the $21^{\text {st }}$ century for the ideological justification of inciting military conflicts and intervention wars on the territory of other states. The methods of lexical and semantic analysis of the collocation "just war" in the comparative paradigm of the Russian and English languages, as well as methods of corpus linguistics and discourse analysis, were used.

The study was based on the materials of the Russian National Corpus and Corpus of Contemporary American English (COCA).

The concept of just war is over 15 millennia old. The earliest reasoning about the moral and ethical aspects of war can be found in the works of Plato and Aristotle. Aristotle in his Politics writes that a war can be recognized as just if it is waged for the sake of protecting one's state or to establish domination over a barbarian state [10].

The most consistent substantiation of just war was offered by the scholastic theologian Saint Augustine. Today, it is transformed into the legal foundations of war.

Thomas Aquinas, developing the concept of just war, writes that a war in which weapons will be used proportionally and in self-defense is allowed. Like Saint Augustine, Aquinas in 
his Summa Theologica [11] notes that it is necessary to experience a feeling of Christian love for the aggressor.

Over the past century, the concept has undergone significant changes. Moral and ethical foundations are replaced by national interests, only disguised by the idea of just war.

\section{Results}

The lexical and semantic analysis of the phrase "just war" and separately the lexemes "just" and "war" was carried out to consider the place of "just war" in the mental vocabulary of native speakers of Russian and American English.

The phrase "just war" occurs 675 times in the COCA. The contexts are categorized into three groups:

1. Just war theory: criticism of just war postulates, just war doctrine, just war norms and standards, followers of just war theory, tradition, arguments, demands.

2. Conditions of just war: belief in a just war, self-defense, the innocence of warriors of a just war, just war as a noble cause.

3. Characteristics of just war: just war (about the war in Iraq), last just war, long-awaited just war.

The same phrase occurs nine times in the Russian National Corpus in the following contexts: just war for the highest values, just war, provided (if we find torture chambers, etc.), just war with anger (righteous anger); just war as an unfair war, not a drunken fight; just war against the world community; just war is on; just war for the Motherland.

Thus, there is a sacralization of just war in Russian and American linguistic cultures. According to M.M. Bakhtin, such texts are a "monad" [12], as they reflect, among other things, biblical texts, forming a special dialogical relationship between them.

Among the main contextual differences in the use of this phrase in Russian and English, it is necessary to highlight the presence of binary opposition.

This is an excerpt from B. Obama's speech during the awarding of the Nobel Peace Prize on December 10, 2009 [13]:

"And over time, as codes of law sought to control violence within groups, so did philosophers and clerics and statesmen seek to regulate the destructive power of war. The concept of a "just war" emerged, suggesting that war is justified only when certain conditions were met: if it is waged as a last resort or in self-defense; if the force used is proportional; and if, whenever possible, civilians are spared from violence. Of course, we know that for most of history, this concept of "just war" was rarely observed. The capacity of human beings to think up new ways to kill one another proved inexhaustible, as did our capacity to exempt from mercy those who look different or pray to a different God".

In this case, a presupposition is a part of a statement containing the idea that the concept of just war appeared to save the world and rid society of violence. The assertive part of the statement becomes the conditions under which the war was recognized as just. Obama uses one more presupposition in his speech, but this time for manipulation, referring to the general background knowledge from the lessons of history that humanity has all the tendencies towards bloody massacre, i.e. posits the depravity of human nature.

The modality of the statement is contained in the predicate (sought to control, seek to regulate), the constitutive meaning of which is negative valence, i.e. failure of the actions taken until the concept of just war was proposed.

Next, we can find the same lexical levels in V.V. Putin's speech about the Great Patriotic War [14].

"It was, without exaggeration, a just war for the very right to live on Earth, to have our own statehood, our own language, culture... The Patriotic War is a just war for freedom and... the army that has become forgotten. This is a forgotten war". 
Factual presupposition includes a component - adverb without exaggeration, the goals of just war act as assertion, modality - for the very right - that is, for the most basic need, the basic foundations of life.

\section{Conclusion}

After the lexical and semantic analysis of the phrase "just war" in Russian and American English, we concluded that in the mental vocabulary of native speakers of Russian and American English, just war is represented by meanings: true, correct, impartial, and legal.

Language becomes the main weapon of a politician when covering military-political events. Discourse should be viewed as "a form of social action, always determined by values and social norms, conventions and social practice, always limited and influenced by power structures and historical processes" [15].

\section{References}

1. K.F. Sedov, Diskurs i lichnost: evoliutsiia kommunikativnoi kompetentsii [Discourse and Personality: Evolution of Communicative Competence] (Labyrinth, Moscow, 2004)

2. O.V. Sokolova, Criticism and Semiotics, 2, 230 (2019)

3. V.V. Krasnykh, The World of Russian Word Journal, 4, 11-15 (2007)

4. M.M. Bakhtin, V.N. Voloshinov, Marksizm i filosofiia iazyka [Marxism and Philosophy of Language], in Tetralogy, 298-456 (Labyrinth, Moscow, 1998)

5. S. Freud, Ia i Ono [The Ego and the Id], 172-198 (Publishing House "E”, Moscow, 2017)

6. V.Z. Demiankov, Political Science. Political Discourse: History and Contemporary Research, 3, 32-43 (2002)

7. A.P. Chudinov, Politicheskaia lingvistika [Political Linguistics], 7 (Flinta, Moscow, 2020)

8. D. Decosimo, The Journal of Religious Ethics, 38(4), 661-697 (2010)

9. T. Van Dijk, Discourse and Society, 4(2), 249-283 (1993)

10. E.L. Kabakhidze, Current Issues in Linguistics, 1(9), 28-37 (2020)

11. Th. Aquinas, Summa Theologica, Part II-II. Questions 1-46 (Nika-Center, Kiev, 2010)

12. M.M. Bakhtin, Problema teksta v lingvistike, filologii i drugikh gumanitarnykh naukakh. Opyt filosofskogo analiza [Issue of the Text in Linguistics, Philology and other Humanities. Experience of philosophical analysis], in Aesthetics of Verbal Art, 300-307 (Moscow, Iskusstvo, 1979)

13. B. Obama, President Obama's speech at Noble ceremony (2009). Accessed on: December 10, 2020. [Online]. Available: https://in.reuters.com/article/idINIndia44627820091210

14. V.V. Putin, Voina s natsizmom stala dlia narodov SSSR Velikoi Otechestvennoi [The war against nazism became the Great Patriotic War for the USSR peoples] (2005). Accessed on: December 10, 2020. [Online]. Available: https://ria.ru/20050508/39949888.html

15. R. Wodak, Critical linguistics and critical discourse analysis. Handbook of pragmatics (Benjamins, Amsterdam, Philadelphia, 1994) 